\title{
PCR-based genotyping of Helicobacter pylori of Gambian children and adults directly from biopsy specimens and bacterial cultures
}

\author{
Ousman Secka ${ }^{*}$, Martin Antonio ${ }^{1}$, Mary Tapgun ${ }^{1}$, Douglas E Berg ${ }^{3}$, Christian Bottomley ${ }^{4}$, Vivat Thomas ${ }^{1}$, \\ Robert Walton ${ }^{1}$, Tumani Corrah ${ }^{1}$, Richard A Adegbola ${ }^{1,5}$ and Julian E Thomas ${ }^{2}$
}

\begin{abstract}
Background: Helicobacter pylori is an important agent of gastroduodenal disease in Africa and throughout the world. We sought to determine an optimum method for genotyping H. pylori strains from children and adults in The Gambia, West Africa.

Results: Virulence genes were amplified in 127 of 190 cases tested (121 adults and 6 children); each of 60 bacterial cultures, and 116 from DNA extracted directly from biopsies. The proportion of biopsies that were cagAt, the ratio of $v a c A s 1 / s 2$, and $v a c A m 1 / \mathrm{m} 2$, and the proportion of mixed strain populations in individual subjects changed with age. Strains lacking virulence cagA and vacA genes and with apparently homogeneous (one predominant strain) infections were more common among infants than adults.

Conclusions: In order to detect the range of bacterial genotypes harbored by individual patients, direct PCR proved slightly superior to isolation of $\mathrm{H}$. pylori by biopsy culture, but the techniques were complementary, and the combination of both culture and direct PCR produced the most complete picture. The seemingly higher virulence of strains from adult than infant infections in The Gambia merits further analysis.
\end{abstract}

Keywords: Genotyping Helicobacter pylori, biopsy specimens, bacterial cultures

\section{Background}

Helicobacter pylori chronically infects over $50 \%$ of people worldwide, causes gastritis and sometimes gastric or duodenal ulceration, and increases the risk of gastric cancer $[1,2]$. Infection also contributes to other maladies such as malnutrition among the very poor, iron deficiency anemia, and susceptibility to other food and water borne pathogens, especially in developing countries, including The Gambia [3,4]. The prevalence of $H$. pylori infection is particularly high in developing countries including The Gambia [5-7]. H. pylori, because it is a fastidious micro-aerobic bacterium, it is technically difficult to grow and maintain for molecular biologic research in poorly resourced laboratories in Africa. These challenges coupled with the uniqueness of

\footnotetext{
* Correspondence: osecka@mrc.gm

${ }^{1}$ Bacterial Diseases Programme, Medical Research Council Laboratories, The Gambia

Full list of author information is available at the end of the article
}

genotypes of African strains and special features of human physiology and environment in this continent limit our understanding of the spectrum of $\mathrm{H}$. pyloriassociated diseases and how this is affected by bacterial genotype in Africa [8,9]. So extensive efforts have been made to determine an optimum method for PCR-based genotyping of $H$. pylori [10-13]. To more effectively investigate the influence of $\mathrm{H}$. pylori genotype on associated diseases in a West African setting, this study sought to determine an optimum method for PCRbased genotyping of $H$. pylori in The Gambia, West Africa.

\section{Results}

A total of 169 biopsy samples from adult subjects, and 21 from infants were investigated for $H$. pylori infections by both culture and PCR of DNA obtained directly from biopsies. 89/169 (52.6\%) adults seemed to be culture positive. Pure H. pylori cultures were obtained from
C Biomed Central

() 2011 Secka et al; licensee BioMed Central Ltd. This is an Open Access article distributed under the terms of the Creative Commons Attribution License (http://creativecommons.org/licenses/by/2.0), which permits unrestricted use, distribution, and reproduction in any medium, provided the original work is properly cited. 
Table 1 Comparison between culture results and direct PCR with Hp specific 16 s primer

\begin{tabular}{lcc}
\hline Result & Culture & Direct by PCR \\
\hline Positive & $89(52.6 \%)$ & $164(97.0 \%)$ \\
\hline Negative & 80 & 5 \\
\hline Total & 169 & 169 \\
\hline
\end{tabular}

only 63 of them, but not the other 26 , primarily because of overgrowth by contaminants despite inclusion of multiple antibiotics in the culture medium or bacterial cells failing to survive further subculture. Direct PCR from adult biopsies indicated that 164/169 (97\%) were positive for Hp16s (table 1). The DNA extracts from the remaining 5 biopsies were $H$. pylori negative with $H p 16 s$ and did not amplify for any of the genes tested, even though they were culture positive. These five samples were tested for PCR inhibitors by spiking them with DNA from a known positive. The spiked samples were also all negative after PCR (data not shown), which implies the presence of a potent inhibitor, possibly a ribonuclease. Virulence gene data were obtained by direct PCR from both biopsies and cultures in 60 cases and these data are used for the comparisons in table 2.
Amongst the 80 culture negative adult subjects for whom Hp16s was positive, amplification of some or all virulence genes was only achieved in 20 cases. It is not yet known if these strains lacked virulence genes, were divergent in primer binding sequences, or the bacterial density was so low that amplification was possible only with the most general of primer combinations, such as Hp16s. The remaining 60 samples did not show amplification for any of the genes tested despite a positive response to Hp16s.

Amongst 21 infants, 8 were $H p 16 s$ positive and pure H. pylori cultures were obtained successfully from six of them. We succeeded in amplifying virulence gene sequences only from the 6 culture positive children. Direct PCR of the biopsies from the other 13 children were either negative $(n=10)$ or not done $(n=3)$.

Virulence gene amplification was successful in 127 (121 adults and 6 children) cases. A comparison of the products that were indicative of cagA (Figure 1), cag emptysite (Figure 2), vacAs alleles (Figure 3), vacAm alleles (Figure 4), iceA1 (Figure 5) and iceA2 (Figure 6) between both methods for detecting $H$. pylori is summarized for 60 samples for which sufficient amplified DNA was obtained for this further analysis. The

Table 2 Comparison of amplification of virulence genes between PCR on bacterial cultures and direct PCR on biopsy material

\begin{tabular}{|c|c|c|c|c|c|c|}
\hline \multicolumn{7}{|c|}{ PCR on Biopsy } \\
\hline Culture & $\operatorname{cagA+}$ & $\begin{array}{l}\text { cag PAI } \\
\text { empty } \\
\text { site }\end{array}$ & $\begin{array}{l}\text { cagA+ } \\
\text { cag PAl } \\
\text { empty } \\
\text { site }\end{array}$ & $\begin{array}{l}\text { No } \\
\text { amplification } \\
\text { with primer }\end{array}$ & $\begin{array}{l}\text { \% Agreement } \\
(95 \% \mathrm{Cl})\end{array}$ & Kappa $(95 \% \mathrm{Cl})$ \\
\hline $\operatorname{Cag} A+$ & $31(52)$ & $0(0)$ & $3(5)$ & $3(5)$ & & \\
\hline $\begin{array}{l}\text { cag PAl } \\
\text { empty site }\end{array}$ & $0(0)$ & $12(20)$ & $0(0)$ & $2(3)$ & & \\
\hline $\begin{array}{l}\text { cagA+ cag } \\
\text { PAl empty }\end{array}$ & $4(7)$ & $1(2)$ & 2(3) & $2(3)$ & $84.9(75.3,94.5)$ & $0.70(0.50,0.91)$ \\
\hline & s1 & $s 2$ & $s 1 \& s 2$ & Missing & & \\
\hline s1 & $31(52)$ & $4(7)$ & $0(0)$ & $5(8)$ & & \\
\hline$s 2$ & $5(8)$ & $9(15)$ & $0(0)$ & $1(2)$ & & \\
\hline$s 1 \& s 2$ & $3(5)$ & $1(2)$ & $0(0)$ & 1(2) & $75.5(63.9,87.1)$ & $0.45(0.21,0.68)$ \\
\hline & $m 1$ & $m 2$ & $m 1 \& m 2$ & Missing & & \\
\hline$m 1$ & $18(30)$ & $1(2)$ & $1(2)$ & $6(10)$ & & \\
\hline$m 2$ & $1(2)$ & $17(28)$ & $0(0)$ & $2(3)$ & & \\
\hline$m 1 \& m 2$ & $4(7)$ & $5(8)$ & $3(5)$ & 2(3) & $76.0(64.2,87.8)$ & $0.62(0.42,0.82)$ \\
\hline & iceA1 & iceA2 & $i c A 1 \& 2$ & Missing & & \\
\hline iceAl & $5(8)$ & $0(0)$ & $1(2)$ & $3(5)$ & & \\
\hline iceA2 & $1(2)$ & $11(18)$ & $29(48)$ & $7(12)$ & & \\
\hline iCeA1\&2 & $0(0)$ & $3(5)$ & $0(0)$ & $0(0)$ & $32.0(19.1,44.9)$ & $0.06(-0.05,0.16)$ \\
\hline
\end{tabular}




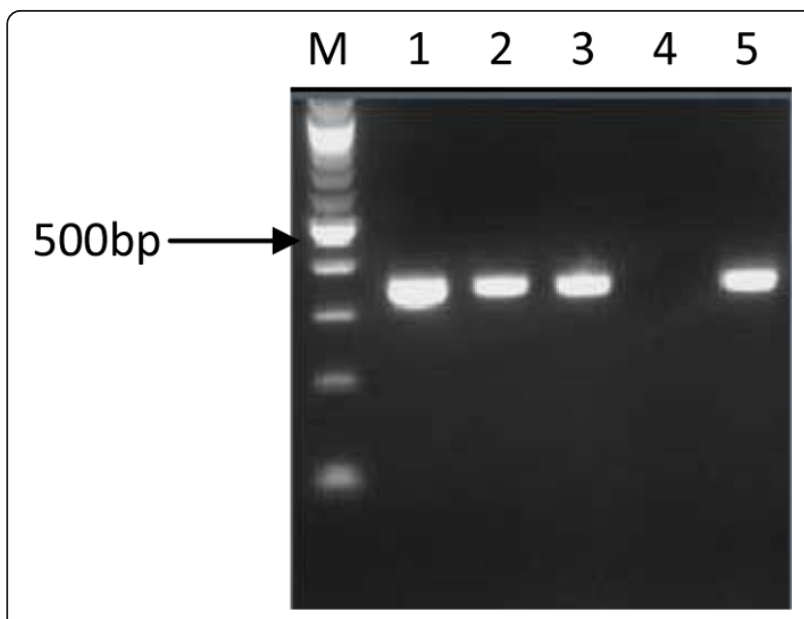

Figure 1 PCR inferred results of cagA gene. $1.5 \% \mathrm{gel}$ electrophoresis of $\mathrm{H}$. pylori genotypes showing PCR results of cagA gene. Lane $\mathrm{M}$ is a $100 \mathrm{bp}$ ladder (Biolabs, UK); lanes 1, 2, 3 and 5 showed PCR products (349 bp) of cagA genes, lane 4 is cagA negative.

proportion of samples that were $\operatorname{cagA+ve}$ with DNA from biopsies and from culture was similar, 58.3\% and $61.7 \%$ respectively. The success in amplification of $v a c A s 1 / s 2$ ( $s 1=$ toxigenic vs $s 2=$ non-toxigenic), $v a c A m 1 / m 2$ and iceA1 alleles was similar from cultures and corresponding biopsies, and agreements between genotypes inferred using DNAs directly from these two sources was good for both cagA and $m 1, m 2$ alleles of $v a c A$, moderate for $s 1, s 2$ alleles of $v a c A$, and poor for ice $A$. The poor agreement in the ice $A$ analysis stemmed from the many classified only as ice $A 2$ by PCR from bacterial culture but iceA1 and ice $A 2$ by biopsy which could have been due to the fact that certain bacterial strains in a mixed infection grew much better than others in culture. In direct PCR up to $16.7 \%$ of culture positive biopsies failed to amplify DNA for individual alleles.

The proportion of biopsies that were $\operatorname{cag} A+$, the proportion of $v a c A s 1$, and $v a c A m 1$, and the proportion of mixed cultures from individual subjects varied with age. Table 3 is a summary of all PCR results, including samples obtained from cultures and from direct PCR on biopsies (127 in total). If subjects were positive by both techniques, only the biopsy amplified sample was included in this analysis. None of the young children had mixed cultures with relation to $\operatorname{cagA}$, vacAs or $v a c A m$ alleles. Young children also exhibited lower levels of the toxigenic genes than any of the adult groups. This difference was only statistically significant $(\mathrm{P} \leq 0.02)$ when isolates obtained from children were compared with those from adults aged less than 60 years for $\operatorname{cag} A$ and $s 1$ allele of $v a c A$, and when compared with isolates from adults aged 41-59 years for $m 1$

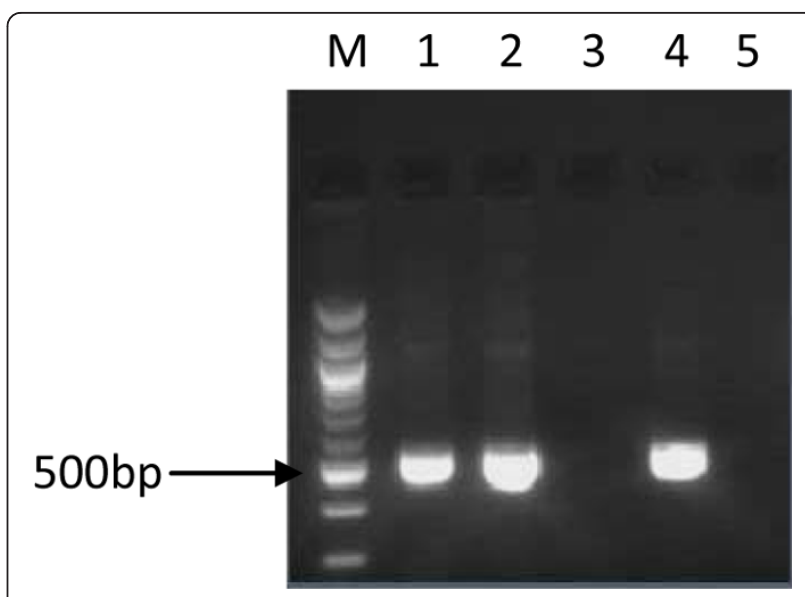

Figure 2 PCR inferred results of cag emptysite. $1.5 \% \mathrm{gel}$ electrophoresis of $H$. pylori genotypes showing PCR results of cag emptysite. Lane M is a 100 bp ladder (Biolabs, UK), lanes 1, 2 and 4 showed PCR products of $535 \mathrm{bp}$ indicating the presence of cag emptysite, lanes 3 and 5 were cag emptysite negative.

region of vacA. However, the sample size in children was small and therefore the difference between children and adults should be interpreted with caution. The prevalence of virulence genes was age-dependent. For $\operatorname{cag} A$, $v a c A s$ and vacAm the virulent genotype was most common among the 30-40 year age group and less common in younger and older age groups. This association was statistically significant $(\mathrm{p}<0.05)$ for $\operatorname{cagA}$ and vacAs and not for the mid region of $v a c A$ gene and ice $A$ alleles ( $\mathrm{p}>0.05$, table 3 ). Only 1 elderly subject (70 years) was found to have mixed colonization with vacAs1/s2. The situation with ice $A$ was more complicated, with a large

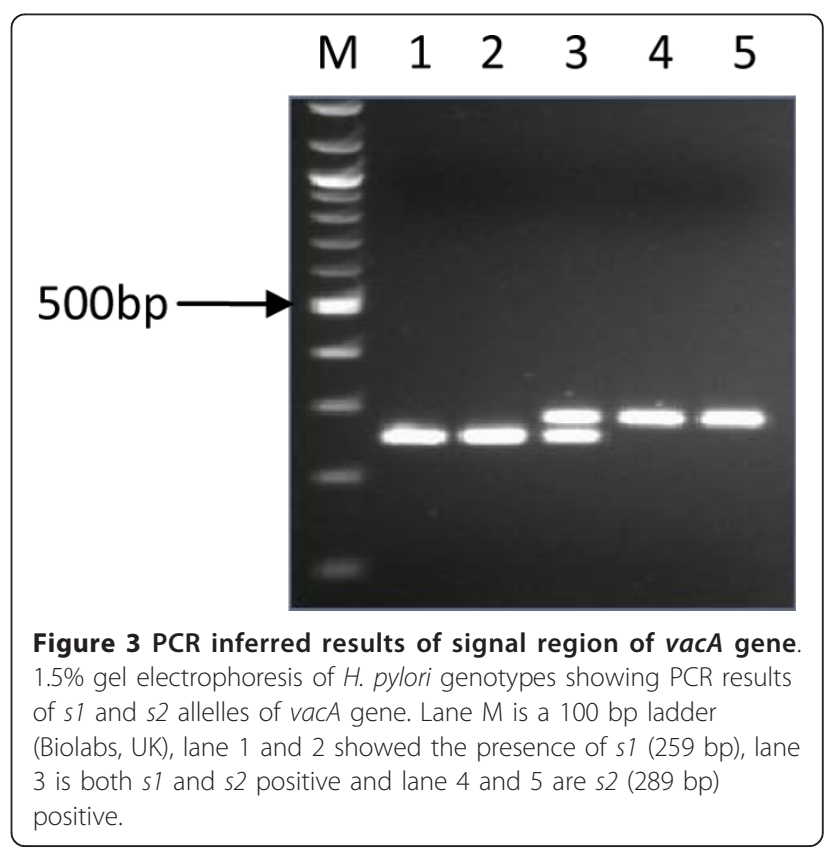




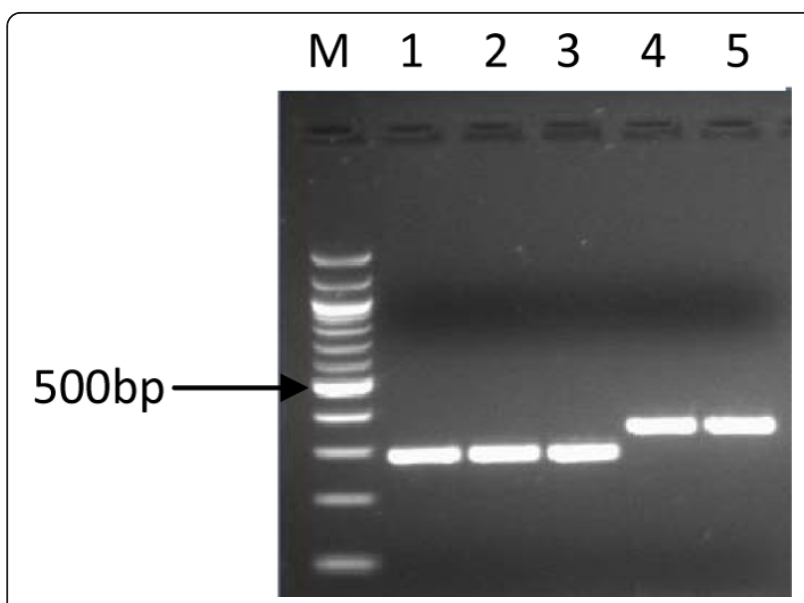

Figure 4 PCR inferred results of mid region of vacA gene. 1.5\% gel electrophoresis of $H$. pylori genotypes showing PCR results of $m 1$ and $m 2$ allelles of vacA gene. Lane $M$ is a 100 bp ladder (Biolabs, UK), lanes 1, 2 and 3 are $m 1$ positive; lanes 4 and 5 showed the presence of $m 2$.

number of individuals exhibiting mixed iceA1/iceA2 colonization.

\section{Discussion}

In this study, we describe the comparison between results obtained from direct PCR to detect $H$. pylori from gastric biopsies in West Africa, compared to PCR of bacterial isolates obtained from the same set of gastric biopsies. Both techniques produced different success rates, as set out in table 1 and both failed to detect $H$. pylori in a significant proportion of infections. We agree with Park et al [14] in that direct PCR can produce inconsistent results, and tend to

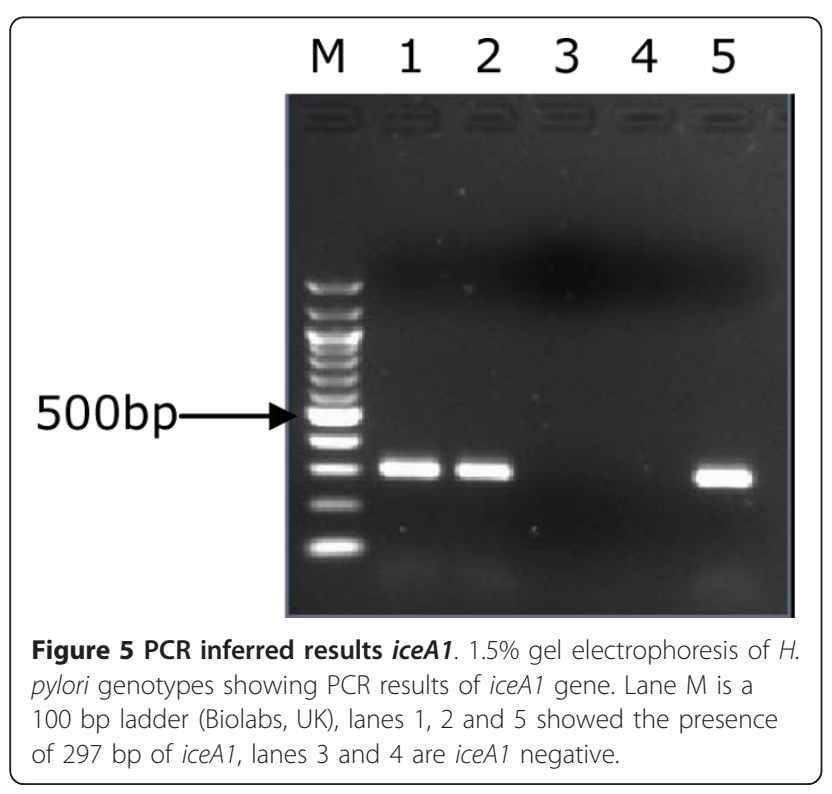

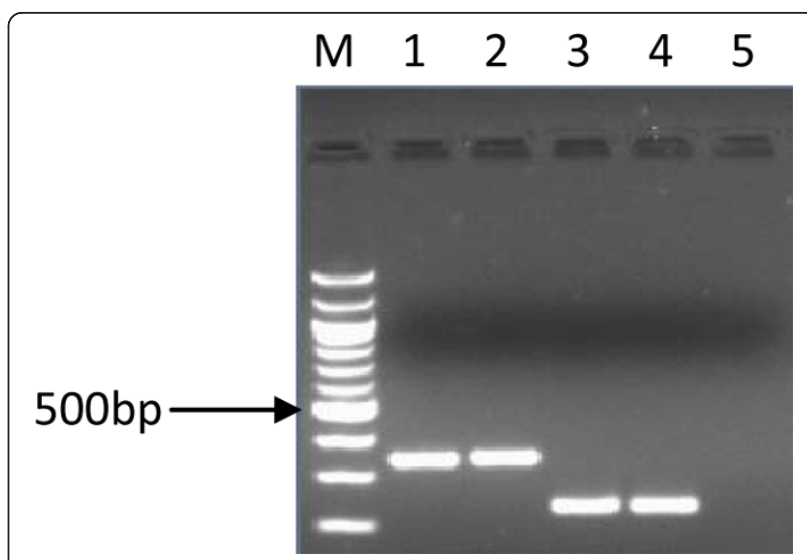

Figure 6 PCR inferred results iceA2. 1.5\% gel electrophoresis of $H$. pylori genotypes showing PCR results of iceA2. Lane $\mathrm{M}$ is a $100 \mathrm{bp}$ ladder (Biolabs, UK), lanes 1 and 2 showed the presence of $334 \mathrm{bp}$ of iceA2 and lanes 3 and 4 were iceA2 positive of $229 \mathrm{bp}$, lane 5 was iceA2 negative.

underestimate the prevalence of specific virulence factors (table 2). However, in this study, we detected a good consistency of genotypes between both techniques consistent with what was reported in a similar study [10].

Our data differs in that we experienced considerably greater difficulty in obtaining pure subcultures of $H$. pylori from gastric biopsies than Park, with a consequently higher failure rate. We have been involved in studies cultivating $H$. pylori from gastric biopsies from populations throughout the world, and it is our personal observation that sub-culture failure is a particular problem amongst West African isolates, as encountered in the present study. The reasons for this are not immediately apparent.

As a consequence of this problem, not all biopsies from which virulence factor DNA was amplified yielded a primary isolation of $H$. pylori, and there was a significant loss of isolates at subculture. PCR from subcultures gave higher rates of mixed colonization for $\operatorname{cag} A$ and $v a c A$ genes than direct PCR of biopsies, in contrast to the situation reported elsewhere with higher culture success rates [14]. This may have been due to artifact, either by enhancement of a minor strain from within the stomach, or due to modification of genome during culture [15]. In our hands, therefore, direct PCR produced more positive results, gave rise to fewer concerns about the development of artifact, and was more rapid and convenient.

Our data also indicate that there may be PCR inhibitors or potent nucleases in some gastric biopsies. This is consistent with findings in similar studies $[12,14]$. Their occasional presence and the underestimated prevalence of specific virulence factors by direct PCR illustrate that 
Table 3 Variation in frequency of alleles with age from samples obtained by PCR directly from biopsies or subcultured H. pylori

\begin{tabular}{|c|c|c|c|c|c|c|}
\hline Age (years) & Total & $\operatorname{cag} A+$ & $\operatorname{cagA-}$ & $\operatorname{cag} A+\&-$ & Not amplified & P-value \\
\hline $1.5-2.5$ & 6 & $1(16.7)$ & $5(83.3)$ & $0(0)$ & $0(0)$ & \\
\hline $9-29$ & 54 & $35(64.8)$ & $10(18.5)$ & $8(14.8)$ & $1(1.8)$ & \\
\hline $30-40$ & 31 & $22(71.0)$ & $2(6.5)$ & $6(19.3)$ & $1(3.2)$ & \\
\hline 41-59 & 24 & $15(62.5)$ & $4(16.7)$ & $4(16.7)$ & $1(4.2)$ & \\
\hline$>=60$ & 12 & $2(16.7)$ & $5(41.7)$ & $5(41.7)$ & $0(0)$ & 0.001 \\
\hline Age (years) & Total & $s 1$ & $s 2$ & $s 1 \& s 2$ & Not amplified & P-value \\
\hline $1.5-2.5$ & 6 & $1(16.7)$ & $5(83.3)$ & $0(0)$ & $0(0)$ & \\
\hline $9-29$ & 54 & $43(79.6)$ & $9(16.7)$ & $0(0)$ & 2(3.7) & \\
\hline $30-40$ & 31 & $27(87.1)$ & $3(9.7)$ & $0(0)$ & $1(3.2)$ & \\
\hline 41-59 & 24 & $18(75.0)$ & $5(20.8)$ & $0(0)$ & $1(4.2)$ & \\
\hline$>=60$ & 12 & $5(41.7)$ & $6(50.0)$ & $1(8.3)$ & $0(0)$ & $<0.001$ \\
\hline Age (years) & Total & $m 1$ & $m 2$ & $m 1 \& m 2$ & Not amplified & P-value \\
\hline $1.5-2.5$ & 6 & $1(16.7)$ & $5(83.3)$ & $0(0)$ & $0(0)$ & \\
\hline $9-29$ & 54 & $25(46.3)$ & $17(31.5)$ & 10(18.5) & 2(3.7) & \\
\hline $30-40$ & 31 & $16(51.6)$ & $8(25.8)$ & $5(16.1)$ & $2(6.5)$ & \\
\hline $41-59$ & 24 & $12(50.0)$ & $4(16.7)$ & $4(16.7)$ & $4(16.7)$ & \\
\hline$>=60$ & 12 & $2(16.7)$ & $7(58.3)$ & $3(25.0)$ & $0(0)$ & 0.103 \\
\hline Age (years) & Total & iceA1 & iceA2 & iceA1\&2 & Not amplified & P-value \\
\hline $1.5-2.5$ & 6 & $3(50.0)$ & $1(16.7)$ & $2(33.3)$ & $0(0)$ & \\
\hline $9-29$ & 54 & 3(5.6) & 19(35.2) & $29(53.7)$ & $3(5.6)$ & \\
\hline $30-40$ & 31 & $6(19.3)$ & $7(22.6)$ & $15(48.4)$ & $3(9.7)$ & \\
\hline 41-59 & 24 & $4(16.7)$ & $10(41.7)$ & $7(29.2)$ & $3(12.5)$ & \\
\hline$>=60$ & 12 & $2(16.7)$ & $6(50.0)$ & $4(33.3)$ & $0(0)$ & 0.065 \\
\hline
\end{tabular}

culture can be a useful complement to direct PCR for studies in which complete ascertainment of $H$. pylori virulence factor genotypes, including mixed colonization, is desired.

We observed a difference in predominant genotype with subjects' age. Young children produced isolates that were more likely to be cagA-ve, and VacAs $2 m 2$, in contrast to adults who were more likely to harbor cagA+ve VacAs $1 m 1$ isolates. Children were also less likely to have mixed populations of $H$. pylori strains, which may relate to children aged 18 to 31 months being relatively recently colonized by $H$. pylori, compared to older individuals. The strains of $H$. pylori discovered in adult stomachs, at ages when typical $H$. pylori associated diseases develop, may be genotypically distinct from the original strains that first colonized young Gambian children. This could be due to recombination of the $H$. pylori genome over the course of decades [16,17] and/or re-exposure to novel strains, with more pathogenic strains circulating predominantly amongst adults.

\section{Conclusion}

In order to detect the range of bacterial genotypes harbored by individual patients, direct PCR proved slightly superior to isolation of $H$. pylori by biopsy culture in our hands, but the techniques were complementary to each other, and the use of both together produced the most complete picture. Despite the lower success rate and greater cost of $H$. pylori culture relative to PCR directly from biopsies, culturing $H$. pylori is still important for antibiotic susceptibility tests that could guide therapy and other phenotypic tests such as bacterial adherence, $\operatorname{cag} A$ and $v a c A$ action on mammalian cells, expression of other colonization and virulence traits for which PCR alone is unsuitable.

\section{Methods}

\section{Patients}

Ethical approval of study protocols was obtained from the joint Gambian Government MRC Ethical Committee and from The London School of Tropical Medicine and Hygiene. 
169 gastric antral biopsies were obtained from adult subjects (50 female and 71 male) undergoing routine diagnostic endoscopy after obtaining informed consent. These subjects were consecutive patients attending the MRC endoscopy clinic for whom the endoscopist decided it was appropriate to take biopsies for research as well as clinical purposes. Patients with severe oesophago-gastroduodenal disease, including gastro-oesophageal varices or gastric cancer, were therefore not included in the study.

In addition, gastric biopsies were obtained, after informed parental consent, from 21 children aged 18 to 31 months, who were undergoing endoscopic small bowel biopsy because of suspected enteropathy.

The biopsies were immediately stored in Brain Heart Infusion (BHI) broth containing $20 \%$ glycerol and transported in ice to the laboratory for processing or stored at $-70^{\circ} \mathrm{C}$ until used.

\section{Culture}

Endoscopic biopsies were spread on the surface of selective Columbia-blood agar (Unipath, Basingstoke, UK) supplemented with 10\% sheep blood (TCS Biosciences, UK), 2\% vitox (Unipath, Basingstoke, UK) and the following antibiotics: trimethoprim $(5 \mu \mathrm{g} / \mathrm{ml})$, vancomycin $(6 \mu \mathrm{g} / \mathrm{ml})$, polymixin B $(10 \mu \mathrm{g} / \mathrm{ml})$, bacitracin $(200 \mu \mathrm{g} /$ $\mathrm{ml})$, nalidixic acid $(10 \mu \mathrm{g} / \mathrm{ml})$, and an antifungal amphotericin B $(8 \mu \mathrm{g} / \mathrm{ml})$ [18]. The inoculated plates were incubated in a micro-aerobic atmosphere at $37^{\circ} \mathrm{C}$ for 5 7 days. Isolation and identification of $H$. pylori was made by colony morphology, Gram stain, oxidase, urease and catalase activity. Strains were preserved in BHI broth containing $20 \%$ glycerol and stored at $-70^{\circ} \mathrm{C}$.

\section{DNA extraction from cultures}

DNA was prepared by harvesting a confluent growth of pooled H. pylori population from agar media and extracted using a commercial kit (QiagenR DNA Mini Kit, UK) as per manufacturer's guidelines. The DNA was stored at $-20^{\circ} \mathrm{C}$ until used for gene amplification.

\section{DNA extraction directly from biopsies}

Total genomic DNA was extracted from the biopsy samples by using a combination of the QIAamp DNA isolation kit (Qiagen, UK) and a bead-beater method. Briefly, biopsies were lysed in $180 \mu \mathrm{l}$ of QIAamp ATL buffer and $20 \mu \mathrm{l}$ of proteinase $\mathrm{K}$ for $1 \mathrm{~h}$ at $56^{\circ} \mathrm{C}$. Glass beads of different diameters $(0.1 \mathrm{~mm}, 0.5 \mathrm{~mm}$ and $1 \mathrm{~mm}$, Sigma) were added, and samples were homogenized in a FastPrep FP120 bead-beater (Bio101, Savant Instruments) for $30 \mathrm{sec}$ at $4 \mathrm{~m} / \mathrm{s}$ and incubated for an additional hour at $56^{\circ} \mathrm{C} .200 \mu \mathrm{l}$ of $\mathrm{AL}$ buffer were added to the lysate and samples were incubated for $30 \mathrm{~min}$ at $70^{\circ} \mathrm{C}$. After the addition of $200 \mu \mathrm{l}$ absolute ethanol, lysates were purified over a QIAamp column as specified by the manufacturer.

\section{PCR amplification of $H$. pylori 16s rRNA}

PCR was performed on extracted DNA from biopsies and also from cultures using $H$. pylori 16s rRNA specific PCR ["Hp16s"] as previously described [19] under the following conditions: 35 cycles of $95^{\circ} \mathrm{C}$ for $30 \mathrm{~s}, 60^{\circ} \mathrm{C}$ for $30 \mathrm{~s}$ and $72^{\circ}$ $\mathrm{C}$ for $30 \mathrm{~s}$ and an extension time of $72^{\circ} \mathrm{C}$ for $5 \mathrm{~min}$. The amplified genes were detected by electrophoresis in a $1.5 \%$ agarose gel with ethidium bromide $(500 \mathrm{ng} / \mathrm{ml})$ and bands visualized using Gel Doc 2000 (Bio-Rad laboratories, Milan, Italy).

\section{PCR to detect genotypes}

PCR was performed to detect $c a g A, v a c A$ genes, iceA1 and iceA2 using previously described methods [20], under the following general conditions: 30 cycles of $94^{\circ}$ $\mathrm{C}$ for $1 \mathrm{~min}, 55^{\circ} \mathrm{C}$ for $1 \mathrm{~min}$ and $72^{\circ} \mathrm{C}$ for $1 \mathrm{~min}$. The amplified genes were detected by electrophoresis in a $1.5 \%$ agarose gel with ethidium bromide and bands were visualized using Gel Doc 2000 (Bio-Rad laboratories, Milan, Italy). The primers used are listed in table 4.

\section{Table 4 Primers used in this study}

\begin{tabular}{|c|c|c|c|c|}
\hline Region & Primer & Nucleotide sequence & bp & reference \\
\hline \multirow{2}{*}{$\begin{array}{l}\text { H. pylori } \\
\text { 16sRNA }\end{array}$} & $\mathrm{Hp} 1$ & ctg gag aga cta agc cct cc & 109 & [19] \\
\hline & $\mathrm{Hp} 2$ & att act gac gct gat tgt gc & & \\
\hline \multirow[t]{2}{*}{$\operatorname{cag} A$} & cagA-F & $\begin{array}{l}\text { gat aac agg caa gct ttt gag } \\
\mathrm{g}\end{array}$ & 349 & {$[20]$} \\
\hline & cagA-R & $\begin{array}{l}\text { ctg caa aag att gtt tgg cag } \\
\text { a }\end{array}$ & & \\
\hline \multirow[t]{2}{*}{ cag empty site } & Luni-1 & $\begin{array}{l}\text { aca ttt tgg cta aat aaa cgc } \\
\text { tg }\end{array}$ & 535 & {$[20]$} \\
\hline & R5280 & $\begin{array}{l}\text { ggt tgc acg cat ttt ccc tta } \\
\text { atc }\end{array}$ & & \\
\hline \multirow[t]{2}{*}{$\begin{array}{l}\operatorname{vacA} s 1 \& \\
\operatorname{vacA} s 2\end{array}$} & Va1-F & atg gaa ata caa caa aça cac & $\begin{array}{l}s 1 \\
259\end{array}$ & {$[20]$} \\
\hline & Va1-R & ctg ctt gaa tgc gcc aaa c & $\begin{array}{l}s 2 \\
289\end{array}$ & \\
\hline \multirow[t]{2}{*}{ vacA mla } & Va3-F & ggt caa aat gcg gtc atg $g$ & 290 & [20] \\
\hline & Va3-R & cca ttg gta cct gta gaa ac & & \\
\hline \multirow[t]{2}{*}{$\operatorname{vacA} m 2$} & Va4-F & gga gcc cca gga aac att g & 352 & [20] \\
\hline & Va4-R & cat aac tag cgc ctt gca c & & \\
\hline \multirow[t]{2}{*}{ iceAl } & 1048-F & $\begin{array}{l}\text { gct tgt aac gat aag aaa cgc } \\
\text { cag at }\end{array}$ & 297 & [20] \\
\hline & $1345 R$ & $\begin{array}{l}\text { gga atg agc ttg tat tta gag } \\
\text { ccg at }\end{array}$ & & \\
\hline \multirow[t]{2}{*}{ iceA2 } & $\begin{array}{l}\text { ICEA2- } \\
F\end{array}$ & gtt ggg tat atc aca att tat & 229 & [20] \\
\hline & $\begin{array}{l}\text { ICEA2- } \\
\mathrm{R}\end{array}$ & ttr ccc tat ttt cta gta ggt & 334 & \\
\hline
\end{tabular}




\section{Statistics}

Percentage agreement was calculated to compare $H$. pylori genotypes obtained by PCR performed directly on gastric biopsies with the genotypes obtained by PCR of DNA extracted from bacteria cultured. In addition, we report the kappa statistic which allows for chance agreement (kappa $=0$ corresponds to no agreement beyond that expected by chance and kappa $=1$ represents perfect agreement).

We studied the prevalence of genotypes within different age categories. The null hypothesis of no association between prevalence and age was tested using Fisher's exact test.

\section{Acknowledgements}

This work was supported in part by grant RO3-AI061308 from the US National Institutes of Health and The Medical Research Council Laboratories, The Gambia.

\section{Author details}

'Bacterial Diseases Programme, Medical Research Council Laboratories, The Gambia. ${ }^{2}$ School of Clinical Medical Sciences, Newcastle University, Newcastle upon Tyne, UK. ${ }^{3}$ Department of Molecular Microbiology, Washington University School of Medicine, St. Louis, USA. ${ }^{4}$ London School of Hygiene and Tropical Medicine, London, UK. ${ }^{5}$ Bill \& Melinda Gates Foundation, Seattle, USA.

\section{Authors' contributions}

JET, RAA and DEB conceived the study. OS performed all the experiments, analysis and wrote the paper with JET, DEB and RAA. TC, JET, MT, RW collected all biopsies from subjects referred for clinical diagnoses. VT participated in consenting of patients and preparing the patients for endoscopy. CB was involved in the statistical analysis. All authors read and approved the final manuscript

\section{Competing interests}

The authors declare that they have no competing interests and the funders had no role in study design, data collection and analysis, decision to publish, or preparation of the manuscript.

Received: 6 March 2011 Accepted: 20 April 2011

Published: 20 April 2011

\section{References}

1. Mbulaiteye SM, H M, El-Omar EM: Helicobacter pylori associated global gastric cancer burden. Front Biosci 2009, 14:1490-504

2. Wu IC, W D, Yu FJ, Wang JY, Kuo CH, Yang SF, Wang CL, Wu MT: Association between Helicobacter pylori seropositivity and digestive tract cancers. World J Gastroenterol 2009, 15(43):5465-71.

3. Akcam M: Helicobacter pylori and micronutrients. Indian Pediatr 2010 , 47(2):119-26

4. Fernández-Bañares $F, M$ H, Forné $M$ : A short review of malabsorption and anemia. Indian Pediatr 2010, 47(2):119-26.

5. Goodman KJ, C P, Tenganá Aux HJ, Ramírez H, DeLany JP, Guerrero Pepinosa O, López Quiñones M, Collazos Parra T: Helicobacter pylori infection in the Colombian Andes. a population-based study of transmission pathways. Am J Epidemiol 1996, 144:290-9.

6. Thomas JE, D A, Harding M, Coward WA, Cole TJ, Weaver LT: Helicobacter pylori colonization in early life. Pediatr Res 1999, 45:218-223.

7. Weaver L: Aspects of Helicobacter pylori Infection in the developing and developed world. Helicobacter pylori infection, nutrition and growth of West African infants. Transactions Royal Soc Trop Med Hygiene 1995, 89:347-50.

8. Campbell DI, W B, Thomas JE, Figura N, Telford JL, Sullivan PB: The African enigma: low prevalence of gastric atrophy, high prevalence of chronic inflammation in West African adults and children. Helicobacter 2001, 6:263-267.

9. Holcombe C: Helicobacter pylori - the African enigma. Gut 1992 33:429-431.

10. Santanu Chattopadhyay, P R, Ramamurthy T, Abhijit Chowdhury, Amal Santra, Dhali GK, Bhattacharya SK, Berg Douglas E, Balakrish GNair, Mukhopadhyay Asish K: Multiplex PCR Assay for Rapid Detection and Genotyping of Helicobacter pylori Directly from Biopsy Specimens. J Clin Microbiol 2004, 42(6):2821-2824.

11. Lim Chang-Young, Cho Myung-Je, Chang Myung-Woong, Kim Seok-Yong, Myong Na-Hye, Lee Woo-Kon, Rhee Kwang-Ho, Kook Yoon-Hoh: Detection of Helicobacter pylori in Gastric Mucosa of Patients with Gastroduodenal Diseases by PCR-Restriction Analysis Using the RNA Polymerase Gene (rpoB). J Clin Microbiol 2003, 41(7):3387-3391.

12. Thoreson A-CE, B M, Andersen LP, JÖrgensen F, Kiilerich S, Scheibel J, Rath J, Krogfelt KA: Helicobacter pylori detection in human biopsies: a competitive PCR assay with internal control reveals false results. FEMS Immunology and Medical Microbiology 1999, 24:201-208.

13. Smith SI, O K, Arigbabu AO, Cantet F, Megraud F, Ojo OO, Uwaifo AO, Otegbayo JA, Ola SO, Coker AO: Comparison of three PCR methods for detection of Helicobacter pylori DNA and detection of cagA gene in gastric biopsy specimens. World J Gastroenterol 2004, 10(3):1958-1960.

14. Park Chang-Young, M K, Gutierrez Oscar, Graham YDavid, Yamaoka Yoshio: Comparison of Genotyping Helicobacter pylori Directly from Biopsy Specimens and Genotyping from Bacterial Cultures. J Clin Microbiol 2003, 41:3336-3338.

15. Hua J, HC N, Yeoh Guan Khay, Ho Bow: Predominance of a Single Strain of Helicobacter pylori in Gastric Antrum. Helicobacter 1999, 4:28-32.

16. Danon SJ, BJ L, Mankoski ERaymond, Eaton AKathryn: RFLP and RAPD Analysis of In Vivo Genetic Interactions Between Strains of Helicobacter pylori. Helicobacter 1998, 3:254-259.

17. Taylor NS, F J, Akopyants NS, Berg DE, Thompson N, Shames B, Yan LL, Fontham E, Janney F, Hunter FM, Correa P: Long-term colonization with single and multiple strains of Helicobacter pylori assessed by DNA fingerprinting. J Clin Microbiol 1995, 33:918-23.

18. Akada JK, O K, Dailidiene D, Dailide G, Cheverud JM, Berg DE: Helicobacter pylori tissue tropism: mouse-colonizing strains can target different gastric niches. Microbiology 2003, 149:1901-9.

19. Sheng-Ang Ho, JA H, Lewis AFraser, Secker DAlison, Cross Debra, Mapstone PNicholas, Dixon FMichael, Wyatt JJudy, Tompkins SDavid, Taylor RGraham, Quirkel Philip: Direct Polymerase Chain Reaction Test for Detection of Helicobacter pylori in Humans and Animals. J Clin Microbiol 1991, 29:2543-2549.

20. Mukhopadhyay AK, D K, Jin-Yong Jeong, Datta Simanti, Ito Yoshiyuki, Chowdhury Abhijit, Chowdhury Sujit, Santra Amal, Bhattacharya KSujit, Azuma Takeshi, Balakrish Nair G, Berg EDouglas: Distinctiveness of genotypes of Helicobacter pylori in Calcutta. India. J Bacteriol 2002, 182:3219-3227.

doi:10.1186/1757-4749-3-5

Cite this article as: Secka et al:: PCR-based genotyping of Helicobacter pylori of Gambian children and adults directly from biopsy specimens and bacterial cultures. Gut Pathogens 2011 3:5.

\section{Submit your next manuscript to BioMed Central and take full advantage of:}

- Convenient online submission

- Thorough peer review

- No space constraints or color figure charges

- Immediate publication on acceptance

- Inclusion in PubMed, CAS, Scopus and Google Scholar

- Research which is freely available for redistribution 